\title{
Obesity: A Gateway Disease with a Rising Prevalence
}

\author{
Gema Frühbeck ${ }^{a, b}$ Volkan Yumuk ${ }^{a, c}$ \\ ${ }^{a}$ European Association for the Study of Obesity, ${ }^{b}$ Department of Endocrinology and \\ Nutrition, Clínica Universidad de Navarra, University of Navarra, CIBERobn, Instituto de \\ Salud Carlos III, Pamplona, Spain, ' Division of Endocrinology, Metabolism and Diabetes, \\ Istanbul University Cerrahpasa Medical Faculty, Istanbul, Turkey
}

\author{
Key Words \\ Obesity $\cdot$ Prevalence $\cdot$ Non-communicable diseases $\cdot$ Comorbidities
}

\section{The European and Global Burden of Obesity}

During the past decades, great advancement in the molecular underpinnings related to obesity, ranging from adipobiology to the neuroendocrine regulation of energy homeostasis and encompassing interorgan cross-talk, inflammation, food composition, reward mechanisms, and genetics, among others, has taken place [1-19]. However, to the despair of both patients and healthcare professionals, this huge understanding has not effectively translated into an evident improvement in the management of obesity with clear-cut positive epidemiological, clinical, and societal outcomes.

Indications for the stagnation of the obesity epidemic are not visible on the horizon. While in 2008, 1.5 billion adults, i.e. 20 years of age and older, were overweight with an estimated 500 million adults worldwide being obese (over 200 million men and nearly 300 million women), the figures of affected individuals are soaring unabatedly. In addition, more than 40 million children under the age of 5 years were overweight in 2010 [20, 21]. It is important to note that severe obesity (i.e. a BMI $>35 \mathrm{~kg} / \mathrm{m}^{2}$ ) is a rapidly growing segment of the obesity epidemic in which the pernicious effects of the disease are especially detrimental. Lately, special attention has been drawn to the high prevalence of overweight in different countries and age groups, as well as the high prevalence of physical inactivity and unhealthy diets $[22,23]$. For all these reasons, the World Health Organization (WHO) has declared obesity as the largest global chronic health problem in adults which is increasingly turning into a more serious world health problem than malnutrition. If recent trends continue, esti- 
mations for 2030 foresee that $60 \%$ of the world's population, i.e. 3.3 billion people, could be overweight ( 2.2 billion) or obese (1.1 billion). Across Europe, the findings of foresight studies towards 2030 parallel the predicted worldwide rapid increases in obesity and require thoughtful consideration [24].

\section{The Silent Menace of Obesity}

According to the WHO, overweight and obesity are considered the fifth leading risk for global deaths [20]. In spite of obesity being a frequent, serious, complex, and chronic disease that represents a major public health concern both at the European and the global level, clear opportunities for its diagnosis and management are being missed [25]. Importantly, the consequences of excess weight impact both directly and indirectly on a broad range of health aspects, expanding from single individuals up to whole nations. Obesity increases a person's risk of developing a number of non-communicable diseases (NCDs) such as cardiovascular disease, diabetes, and cancer [26]. The WHO emphasizes that $44 \%$ of the diabetes burden, $23 \%$ of the ischaemic heart disease burden, and approximately $7-41 \%$ of certain cancer burdens are attributable to overweight and obesity [20,27]. In the majority of European countries, overweight and obesity are responsible for about $80 \%$ of the cases of type 2 diabetes, $35 \%$ of ischaemic heart disease, and 55\% of hypertensive disease among adults. This places obesity at the forefront of the fight against NCDs. Moreover, the risk of developing more than one of these comorbidities also increases with an elevated body weight. It is noteworthy that lifestyle interventions with weight loss have been reported to significantly reduce the risk of progression to type 2 diabetes in large-scale clinical studies with long-term followup [28-31].

Excess body weight also puts patients at a higher risk of stroke, sleep apnoea, dyslipidaemia, and other serious obesity-associated diseases. Furthermore, increased adiposity is accompanied by a chronic low-grade inflammation with elevated proinflammatory cytokines that elevate the cardiometabolic risk but decrease following weight loss [32]. Moreover, it has been recently reported that obese individuals are at an increased risk for adverse long-term outcomes even in the absence of metabolic alterations, thereby indicating that there is no healthy pattern of increased body weight $[33,34]$. In addition, a range of debilitating conditions such as osteoarthritis, respiratory difficulties, gallbladder disease, infertility, and psychological problems, which lead to a reduced life expectancy and quality of life as well as disability, are extremely costly in terms of both absence from work and use of health resources. In spite of huge efforts and research investment, obesity has become one of the leading causes of death and disability worldwide. It is estimated that obesity is responsible for $2-8 \%$ of health costs and $10-13 \%$ of deaths in the European region $[20,35,36]$.

\section{The Challenge of Obesity}

The disease burden in public health has moved from acute disease situations towards chronic diseases and NCDs, thereby representing a paradigm change which requires a shift concerning how prevention and care are provided [37]. Obesity threatens to overwhelm societies and healthcare systems as it complicates clinical care with its associated diseases, increases healthcare costs, limits quality of life as well as life expectancy, and affects socioeconomic development. Thus, obesity should be a top priority for a united Europe, with increased commitment for concerted, coordinated, and specific actions focused on strategically tackling the epidemic. Given that the causes of obesity are embedded in an extraordi- 
Frühbecka,b and Yumuka,c: Obesity: A Gateway Disease with a Rising Prevalence

narily complex biological system set within an equally complicated environmental and societal framework, careful attention should be paid to making healthy choices about food, hydration, and exercise accessible to citizens.

A comprehensive, realistic, pro-active, long-term strategy with multidimensional initiatives and fresh perspectives on easily applicable preventive measures is required to design a sustainable response to deal with the challenges posed by this epidemic. Moreover, irrespective of their BMI, the identification of those individuals truly requiring healthcare and a personalised approach should be encouraged via the instauration and implementation of programmes for early competent prevention, diagnosis, and management with thoughtful, innovative, and evidence-based interventions addressing both individual citizens and the environmental context they live in.

Integrating and mobilising all relevant scientific disciplines, i.e. building true trans-disciplinary research, is needed to address obesity as a complex phenomenon considering biological as well as psychosocial interindividual variability. In this regard, improvement and development of our knowledge as well as understanding of disease aetiology at the individual, population, and societal level will only derive from a combined accurate assessment placing the emphasis on detailed analyses of the many biologic, environmental, cultural, geographical, and social influences.

\section{Disclosure Statement}

No conflicts of interest.

\section{References}

1 Zhang Y, Proenca R, Maffei M, Barone M, Leopold L, Friedman JM: Positional cloning of the mouse obese gene and its human homologue. Nature 1994;372:425-432.

-2 Frühbeck G, Alonso R, Marzo F, Santidrián S: A modified method for the indirect quantitative analysis of phytate in foodstuffs. Anal Biochem 1995;225:206-212.

-3 Frühbeck G, Gómez Ambrosi J: Rationale for the existence of additional adipostatic hormones. FASEB J 2001; 15:1996-2006.

-4 Frühbeck G, Gómez Ambrosi J, Salvador J: Leptin-induced lipolysis opposes the tonic inhibition of endogenous adenosine in white adipocytes. FASEB J 2001;15:333-340.

5 Gómez-Ambrosi J, Frühbeck G: Do resistin and resistin-like molecules also link obesity to inflammatory diseases? Ann Intern Med 2001;135:306-307.

-6 Muruzábal FJ, Frühbeck G, Gómez-Ambrosi J, Archanco M, Burrell MA: Immunocytochemical detection of leptin in non-mammalian vertebrate stomach. Gen Comp Endocrinol 2002;128:149-152.

7 Frühbeck G: Obesity: aquaporin enters the picture. Nature 2005;438:436-437.

-8 Gómez-Ambrosi J, Salvador J, Rotellar F, Silva C, Catalán V, Rodríguez A, Jesús Gil M, Frühbeck C: Increased serum amyloid A concentrations in morbid obesity decrease after gastric bypass. Obes Surg 2006;16:262269.

-9 Catalán V, Gómez-Ambrosi J, Rotellar F, Silva C, Rodríguez A, Salvador J, Gil MJ, Cienfuegos JA, Frühbeck G: Validation of endogenous control genes in human adipose tissue: relevance to obesity and obesity-associated type 2 diabetes mellitus. Horm Metab Res 2007;39:495-500.

10 Moreno-Navarrete JM, Catalán V, Ortega F, Gómez-Ambrosi J, Ricart W, Frühbeck G, Fernández-Real JM: Circulating omentin concentration increases after weight loss. Nutr Metab 2010;7:27.

11 Drgonova J, Jacobsson JA, Han JC, Yanovski JA, Fredriksson R, Marcus C, Schiöth HB, Uhl GR: Involvement of the neutral amino acid transporter SLC6A15 and leucine in obesity-related phenotypes. PLoS One 2013; 8:e68245.

12 Gill R, Him Cheung Y, Shen Y, Lanzano P, Mirza NM, Ten S, Maclaren NK, Motaghedi R, Han JC, Yanovski JA, Leibel RL, Chung WK: Whole-exome sequencing identifies novel LEPR mutations in individuals with severe early onset obesity. Obesity (Silver Spring) 2014;22:576-584.

13 Harms M, Seale P: Brown and beige fat: development, function and therapeutic potential. Nat Med 2013;19: 1252-1263.

14 Lizaso A, Tan KT, Lee YH: Beta-adrenergic receptor-stimulated lipolysis requires the RAB7-mediated autolysosomal lipid degradation. Autophagy 2013;9:1228-1243. 
15 Shalata A, Ramirez MC, Desnick RJ, et al: Morbid obesity resulting from inactivation of the ciliary protein CEP19 in humans and mice. Am J Hum Genetics 2013;93:1061-1071.

16 Stice E, Figlewicz DP, Gosnell BA, Levine AS, Pratt WE: The contribution of brain reward circuits to the obesity epidemic. Neurosci Biobehav Rev 2013;37:2047-2058.

17 Thiam AR, Farese RV Jr, Walther TC: The biophysics and cell biology of lipid droplets. Nat Rev Mol Cell Biol 2013;14:775-786.

18 Wang J, Liu R, Wang F, Hong J, Li X, Chen M, Ke Y, Zhang X, Ma Q, Wang R, Shi J, Cui B, Gu W, Zhang Y, Zhang Z, Wang W, Xia X, Liu M, Ning G: Ablation of LGR4 promotes energy expenditure by driving white-to-brown fat switch. Nat Cell Biol 2013;15:1455-1463.

19 Zhang Y, Marsboom G, Toth PT, Rehman J: Mitochondrial respiration regulates adipogenic differentiation of human mesenchymal stem cells. PLoS One 2013;8:e77077.

20 World Health Organization: Fact Sheet: Obesity and Overweight. www.who.int/mediacentre/factsheets/fs311/ en/.

21 Olshansky SJ, Antonucci T, Berkman L, Binstock RH, Boersch-Supan A, Cacioppo JT, Carnes BA, Carstensen LL, Fried LP, Goldman DP, Jackson J, Kohli M, Rother J, Zheng Y, Rowe J: Differences in life expectancy due to race and educational differences are widening, and many may not catch up. Health Aff (Millwood) 2012;31:18031813.

22 World Health Organization: Obesity. www.euro.whoint/en/what-we-do/health-topics/noncommunicablediseases/obesity.

-23 Ezzati M, Riboli E: Behavioral and dietary risk factors for noncommunicable diseases. N Engl J Med 2013;369: 954-964.

24 Kelly T, Yang W, Chen CS, Reynolds K, He J: Global burden of obesity in 2005 and projections to 2030. Int J Obes (Lond) 2008;32:1431-1437.

25 Frühbeck G: Obesity. Screening for the evident in obesity. Nat Rev Endocrinol 2012;8:570-572.

26 Clark H: NCDs: a challenge to sustainable human development. Lancet 2013;381:510-511.

27 Frühbeck G, Toplak H, Woodward E, Yumuk V, Maislos M, Oppert JM: Obesity: the gateway to ill health - an EASO position statement on a rising public health, clinical and scientific challenge in Europe. Obes Facts 2013; 6:117-120.

28 Pan XR, Li GW, Hu YH, Wang JX, Yang WY, An ZX, Hu ZX, Lin J, Xiao JZ, Cao HB, Liu PA, Jiang XG, Jiang YY, Wang JP, Zheng H, Zhang H, Bennett PH, Howard BV: Effects of diet and exercise in preventing NIDDM in people with impaired glucose tolerance. The Da Qing IGT and Diabetes Study. Diabetes Care 1997;20:537-544.

-29 Tuomilehto J, Lindström J, Eriksson JG, Valle TT, Hämäläinen H, Ilanne-Parikka P, Keinänen-Kiukaanniemi S, Laakso M, Louheranta A, Rastas M, Salminen V, Uusitupa M; Finnish Diabetes Prevention Study Group: Prevention of type 2 diabetes mellitus by changes in lifestyle among subjects with impaired glucose tolerance. N Engl J Med 2001;344:1343-1350.

-30 Knowler WC, Barrett-Connor E, Fowler SE, Hamman RF, Lachin JM, Walker EA, Nathan DM; Diabetes Prevention Program Research Group: Reduction in the incidence of type 2 diabetes with lifestyle intervention or metformin. N Engl J Med 2002;346:393-403.

-31 Lindström J, Peltonen M, Eriksson JG, Ilanne-Parikka P, Aunola S, Keinänen-Kiukaanniemi S, Uusitupa M, Tuomilehto J; for the Finnish Diabetes Prevention Study (DPS): Improved lifestyle and decreased diabetes risk over 13 years: long-term follow-up of the randomised Finnish Diabetes Prevention Study (DPS). Diabetologia 2013;56:284-293.

-32 Catalán V, Gómez-Ambrosi J, Ramirez B, Rotellar F, Pastor C, Silva C, Rodríguez A, Gil MJ, Cienfuegos JA, Frühbeck G: Proinflammatory cytokines in obesity: impact of type 2 diabetes mellitus and gastric bypass. Obes Surg 2007;17:1464-1474.

33 Hill JO, Wyatt HR: The myth of healthy obesity. Ann Intern Med 2013;159:789-790.

34 Kramer CK, Zinman B, Retnakaran R: Are metabolically healthy overweight and obesity benign conditions?: a systematic review and meta-analysis. Ann Intern Med 2013;159:758-769.

-35 Finkelstein EA, Trogdon JG, Cohen JW, Dietz W: Annual medical spending attributable to obesity: payer- and service-specific estimates. Health Aff (Millwood) 2009;28:w822-831.

-36 Grieve E, Fenwick E, Yang HC, Lean M: The disproportionate economic burden associated with severe and complicated obesity: a systematic review. Obes Rev 2013;14:883-894.

-37 Schroeder SA: Shattuck Lecture. We can do better - improving the health of the American people. N Engl J Med 2007;357:1221-1228. 